Nevada

Environmental

Restoration

Project

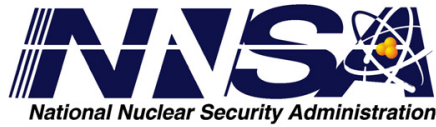

Addendum to the Corrective Action

Decision Document/Closure Report for

Corrective Action Unit 372: Area 20

Cabriolet/Palanquin Unit Craters

Nevada National Security Site, Nevada

Controlled Copy No.:

Revision No.: 0

January 2012

Approved for public release; further dissemination unlimited.

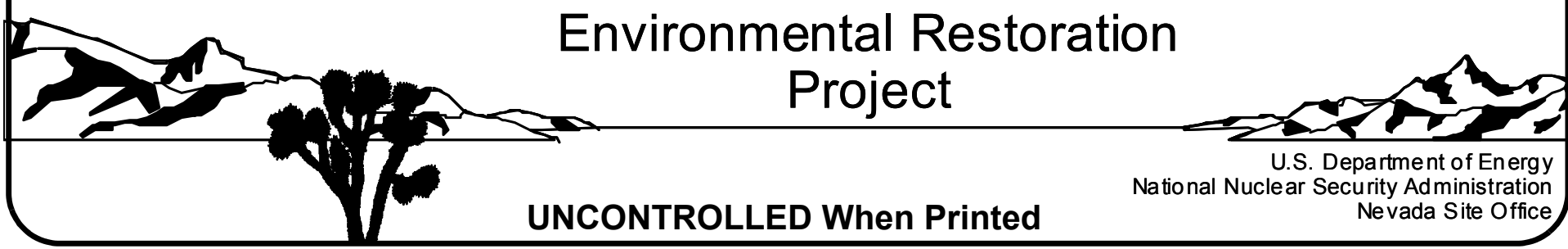


Available for sale to the public from:

U.S. Department of Commerce

National Technical Information Service

5301 Shawnee Road

Alexandria, VA 22312

Telephone: 800.553 .6847

Fax: 703.605.6900

E-mail: orders@ntis.gov

Online Ordering: http://www.ntis.gov/help/ordermethods.aspx

Available electronically at http://www.osti.gov/bridge

Available for a processing fee to U.S. Department of Energy and its contractors, in paper, from:

U.S. Department of Energy

Office of Scientific and Technical Information

P.O. Box 62

Oak Ridge, TN 37831-0062

Phone: 865.576 .8401

Fax: 865.576.5728

Email: reports@adonis.osti.gov

Reference herein to any specific commercial product, process, or service by trade name, trademark, manufacturer, or otherwise, does not necessarily constitute or imply its endorsement, recommendation, or favoring by the United States Government or any agency thereof or its contractors or subcontractors. 


\title{
ADDENDUM TO THE CORRECTIVE ACTION DECISION DOCUMENT/CLOSURE REPORT FOR CORRECTIVE ACTION UNIT 372: AREA 20 CABRIOLET/PALANQUIN UNIT CRATERS NEVADA NATIONAL SECURITY SITE, NEVADA
}

\author{
U.S. Department of Energy \\ National Nuclear Security Administration \\ Nevada Site Office \\ Las Vegas, Nevada
}

Controlled Copy No.:

Revision No.: 0

January 2012

Approved for public release; further dissemination unlimited. 
ADDENDUM TO THE CORRECTIVE ACTION DECISION DOCUMENT/CLOSURE REPORT FOR CORRECTIVE ACTION UNIT 372:

AREA 20 CABRIOLET/PALANQUIN UNIT CRATERS NEVADA NATIONAL SECURITY SITE, NEVADA

Approved by: /s/ Kevin J. Cabble

Date: $01 / 24 / 2012$

Kevin J. Cabble

Federal Sub-Project Director

Soils Sub-Project

Approved by: /s/ Robert F. Boehlecke

Date: $01 / 25 / 2012$

Robert F. Boehlecke

Federal Project Director

Environmental Restoration Project 


\section{Addendum to the Corrective Action Decision Document/Closure Report for Low-Level Waste Disposal Documentation}

This document constitutes an addendum to the Corrective Action Decision Document/Closure Report for Corrective Action Unit 372: Area 20 Cabriolet/Palanquin Unit Craters, Nevada Test Site, Nevada (Revision 0), April 2011. In conformance with Attachment D-1 of the above-mentioned document, this addendum consists of:

- The Certificate of Disposal for the LLW generated during the CAU 372 investigation

The following Certificate of Disposal provides documentation verifying the disposal of low-level waste generated at CAU 372 and accumulated in container number 566007 at the Nevada National Security Site Radioactive Waste Management Complex in Area 5 on July 28, 2011.

\section{References}

U.S. Department of Energy, National Nuclear Security Administration Nevada Site Office. 2011. Corrective Action Decision Document/Closure Report for Corrective Action Unit 372: Area 20 Cabriolet/Palanquin Unit Craters, Nevada National Security Site, Nevada, Rev. 0, DOE/NV--1444. Las Vegas, NV. 


\section{Certificate of Disposal}

This is to certify that the Waste Stream No. LITN-000000006, Revision 14, shipment number ITL1 1008, with container number 566007 was shipped and received at the Nevada National

Security Site Radioactive Waste Management Complex in Area 5 for disposal as stated below.

Nicole Nastanski

Shipped by

/s/ Nicole Nastanski

Signature

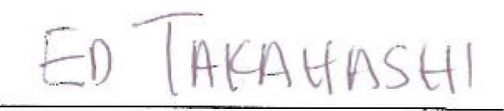

Received by

/s/ Ed Takahashi

प/ Signature
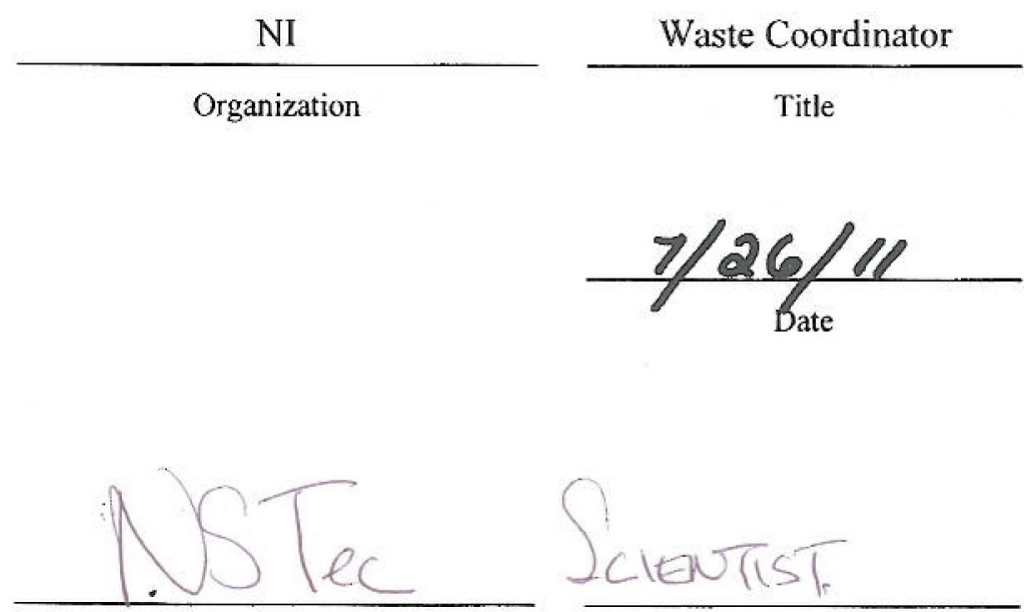

Organization

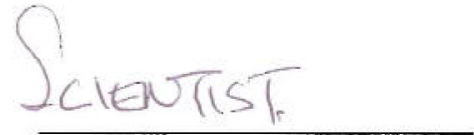

Title

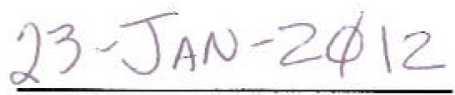

Date 


\section{Library Distribution List}

Date: January 2012

\section{$\underline{\text { Copies }}$}

U.S. Department of Energy

National Nuclear Security Administration

Nevada Site Office

Technical Library

P.O. Box 98518, M/S 505

Las Vegas, NV 89193-8518

U.S. Department of Energy

Office of Scientific and Technical Information

P.O. Box 62

Oak Ridge, TN 37831-0062

Southern Nevada Public Reading Facility

c/o Nuclear Testing Archive

P.O. Box 98521, M/S 400

Las Vegas, NV 89193-8521

Manager, Northern Nevada FFACO

Public Reading Facility

c/o Nevada State Library \& Archives

100 N Stewart Street

Carson City, NV 89701-4285
1 (Uncontrolled, electronic copy)

1 (Uncontrolled, electronic copy)

2 (Uncontrolled, electronic copies)

1 (Uncontrolled, electronic copy) 